\title{
Evolution of ribosomal internal transcribed spacers in Deuterostomia
}

Alexandr Dyomin, Valeria Volodkina, Elena Koshel, Svetlana Galkina, Alsu Saifitdinova, Elena Gaginskaya

Biological Faculty of Saint-Petersburg State University, Universitetskaya emb. 7/9, SaintPetersburg 199034, Russia

e-mails:_rustle.reed@gmail.com,_leravolo94@gmail.com,_opossum39@mail.ru, svetlana.galkina@mail.ru, saifitdinova@mail.ru, elena.gaginskaya@gmail.com

\section{Abbreviations}

HTS - high-throughput sequencing; IGS - intergenic spacer; ITS - internal transcribed spacer; WGS - whole genome sequence shotgun; SRA - sequence read archive; MGC - mobile genetic elements; gBGC - GC-biased gene conversion. 


\begin{abstract}
Sequences of ribosomal internal transcribed spacers (ITSs) are of great importance to molecular phylogenetics and DNA barcoding, but remain unstudied in some large taxa of Deuterostomia. We have analyzed complete ITS1 and ITS2 sequences in 62 species from 16 Deuterostomia classes, with ITSs sequences in 24 species from 11 classes initially obtained using unannotated contigs and raw read sequences. A general tendency for both ITS length and GC-content increase from interior to superior Deuterostomia taxa, a uniform GC-content in both ITSs within the same species, thymine content decrease in sense DNA sequences of both ITSs are shown. A possible role of GC-based gene conversion in Deuterostomia ITSs evolutionary changes is hypothesized. The first example of non-LTR retrotransposon insertion into ITS sequence in Deuterostomia is described in turtle Geochelone nigra. The roles of mobile genetic element insertions in the evolution of ITS sequences in some Sauropsida taxa are discussed as well.
\end{abstract}

\title{
Keywords
}

rDNA evolution, internal transcribed spacers, Deuterostomia, Sauropsida, GC-content, nucleotide compositional shift

\section{Introduction}

Repetitive ribosomal RNA genes belong to key elements in Metazoan genome. Yet their structure, functioning and evolution still give rise to endless questions. rDNA repeat units correspond to rDNA transcriptional units coding pre-rRNA molecules separated from each other by intergenic spacers (IGS). Each pre-rRNA transcriptional unit consists of $18 S, 5.8 S$ and $28 S$ rRNA genes and separating internal transcribed spacers, ITS1 and ITS2 (Fig. 1) (Singer and Berg, 1991). Gene sequences are highly conservative and have been throughly investigated in various animal taxa. Contrarily, spacer sequences are highly variable, both length- and nucleotide content-wise.

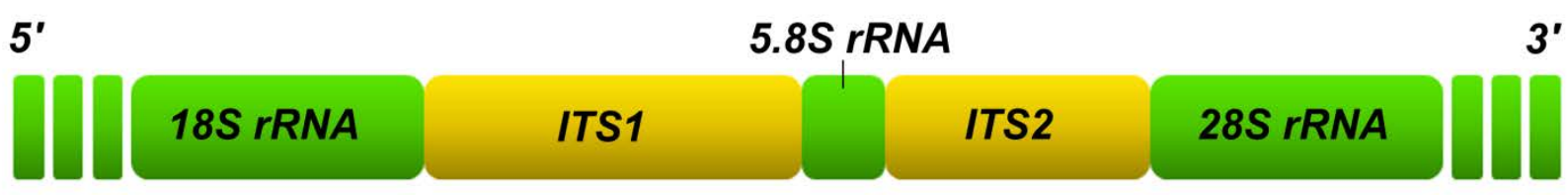

Fig. 1. ITS1 and ITS2 positions within a rDNA transcription unit

Exploration of ITS1 and ITS2 transcribed in pre-rRNA is of special importance. So far their function (presumed regulatory role) so far has remained unclear. However, this high variability resulting from nucleotide substitutions, deletions and insertions turns ITSs sequences 
into a convenient molecular and genetic marker for eucaryotic taxonomy (Yao et al., 2010; Wang et al., 2015). ITSs sequences are widely used as phylogenic markers in population and species-grade analysis (Zagoskin et al., 2014). Due to their high variability, ITSs sequences can be used in analysis of rDNA repeat unit evolution (Naidoo et al., 2013).

ITSs sequences have been throughly analyzed in plants (Chen et al., 2010), fungi (Bellemain et al., 2010) and some Protostomia (Cornman et al., 2015). However, Deuterostoma rRNA structure and evolution, specifically ITS1 and ITS2 sequences, are underinvestigated. An exception can be made for some fish and placental mammalian species for which complete sequences of both ITSs have been decoded (Coleman, 2013; Wang et al., 2015). ITS2 structure has been also described for some reptile species (Kupriyanova et al., 2012). For most of other Deuterostomia taxa, ITSs sequences are available only for individual species. It is worth noting that NCBI ITS annotations for Deuterostomia frequently contain incorrect data on generic identity and size of the spacers (Coleman, 2013; Dyomin et al., 2016). So far no studies ITSs structural evolution covering the entire versatility of modern Deutorostomia classes have been conducted.

Such lack of knowledge about Deuterostomia ITSs is very likely to be related to their extensive length and high GC-content (Dyomin et al., 2016). These peculiarities of ITSs prevent PCR and traditional capillary sequencing application for their primary structural analysis. High GC-content and existence of low complexity regions also impact high-throughput sequencing (HTS) of Deuterostomia ITSs sequences. Nonetheless, today HTS findings are the most promising data source for ITSs analysis in higher chordate taxa (Coleman, 2013; Dyomin et al., 2016). Due to progress of animal HTS projects (Koepfli et al., 2015), currently data on genomes of over 300 species of various Deuterostomia classes are available (http://www.ncbi.nlm.nih.gov/genome). They are stored in NCBI libraries (Assembly, WGS and SRA) in contig and raw read format. Unannotated contigs and raw reads can contain ITSs fragments that can be used for complete sequence assembly (Coleman, 2013; Dyomin et al., 2016).

In this article we have compared ITS1 and ITS2 structures of species from 16 Deuterostomia classes. We have identified the common aspects and differences in ITS1 and ITS2 of species of various Deuterostomia evolutionary branches. Assumptions on evolutionary patterns of ITS sequences in Deuterostomia have been offered.

\section{Material and methods}

Apart from previously published Deuerostomia ITS1 and ITS2 sequences, we have compared ITSs sequences assembled de novo from raw reads and contigs found in NCBI 
libraries. We have used three data categories: 1) sequences annotated as ITSs of individual species in Nucleotide database (http://www.ncbi.nlm.nih.gov/nuccore/); 2) unannotated contig sequences from Assembly database (http://www.ncbi.nlm.nih.gov/assembly/) and 3) unannotated raw read sequences from SRA database (http://www.ncbi.nlm.nih.gov/sra/).

Unannotated sequences containing ITSs fragments we identified with the aid of BLAST algorithm (https://blast.ncbi.nlm.nih.gov/Blast.cgi). Fragments of mobile components of ITSs sequences were identified in Repbase on on-line basis (http://www.girinst.org/repbase/index.html). De novo sequence assembly from contigs and raw reads was performed in Geneious v 9.1.5. (http://www.geneious.com/). Most of ITSs Mammalia sequences were borrowed from the assembly published by Coleman (2013). Spacer boundaries were identified with the aid of human rDNA repeat unit annotations (NCBI, Nucleotide: U13369) and chicken rRNA gene cluster (NCBI, Nucleotide: KT445934). Nucleotide structure of the sequences was analyzed in MEGA v6.0 (http://www.megasoftware.net/). The data were processed in Statistica v6.0 (http://www.statsoft.com/).

We have analyzed ITS1 and ITS2 performed for 4 types: Chaetognatha, Echinodermata, Hemichordata and Chordata. The outgroup consisted of Ctenophora and Cnidaria species. In Chordata ITSs sequences have been analyzed for species of all major classes.

Deuterostomia taxonomy was based on NCBI Taxonomy (http://www.ncbi.nlm.nih.gov/taxonomy/). The analyzed taxa are grouped in the charts based on the phylogenic trees proposed by Dunn et al. (2008), Jarvis et al. (2015) and Hedges et al. (2015).

\section{Results}

\subsection{ITS sequences search and assembly for analysis}

We have analyzed complete ITS1 and ITS2 sequences for 62 species (see Table). The Table contains references to the taxonomic status of each of the species, complete GC length and content for both ITS sequences and source of ITS sequences data for each species. For 32 species, including six outgroup members, we have used NCBI ITSs that had been earlier annotated by other authors. These sequences cover the entire analyzed data array on Chaetognatha type and Chondrichthyes and Actinopterygii classes from Chordata. Some sequences earlier annotated in GenBank as ITS1 and ITS2 fragments related to the analyzed Deuterostomia species were excluded from the analysis due to low quality of the related assemblies or wrong annotation. The analyzed spacer sequences of 13 mammalian species were earleier described by Coleman (2013). Spacers for 15 species were assembled on the basis of unannotated contigs. For Petromyzon marinus, a Cyclostomata species, a combined spacer 
assembly was performed on the basis of an NCBI annotated sequence (NCBI, Nucleotide: AF061798) and unannotated contig sequences.

Most challenging was ITSs analysis in Aves, one of the most progressive classes among Deuterostomia. So far transcribed avian ribosome RNA spacers have remained virtually unknown (Dyomin et al., 2016). An article by Kupriyanova et al., (2012) mentions zebra finch ITS2 assembly, yet, unfortunately, the complete sequence has not been disclosed. Earlier we annotated in NCBI the first complete assembly of chicken rRNA gene cluster sequence containing both ITSs (NCBI, Nucleotide: KT445934). In this survey we have assembled from unannotated contigs one ITSs for each of the two Psittaciformes species. We have also been able to decode the complete structure of both ITSs for 8 species from 6 avian orders using de novo assembly from WGS raw reads. We have also established ITS2 sequence for Zonotrichia albicollis (Passeriformes, Aves).

In total, we have been the first to analyzed ITSs structure for 24 species from 11 Deuterostomia classes. All sequences used, including those first assembled in this study, are listed in Supplementary File 1.

Table ITS1 and ITS2 lengths and GC-content in Deuterostomia representatives

\begin{tabular}{|c|c|c|c|c|c|c|}
\hline \multirow[t]{2}{*}{ Taxonomic group } & \multirow[t]{2}{*}{ Species } & \multicolumn{2}{|c|}{ ITS1 } & \multicolumn{2}{|c|}{ ITS2 } & \multirow{2}{*}{$\begin{array}{c}\text { Source } \\
\text { (*unannotated sequences) }\end{array}$} \\
\hline & & $\mathrm{L}$ & GC\% & $\mathrm{L}$ & GC\% & \\
\hline \multicolumn{7}{|c|}{ phylum CTENOPHORA } \\
\hline class Nuda & Beroe cucumis & 210 & 48.6 & 226 & 53.5 & AF293699 \\
\hline \multirow[t]{2}{*}{ class Tentaculata } & Pleurobrachia sp. & 215 & 46.5 & 274 & 50.0 & KP099828 \\
\hline & Hormiphora plumosa & 260 & 54.2 & 283 & 53.0 & AF293676 \\
\hline \multicolumn{7}{|c|}{ phylum CTENOPHORA } \\
\hline class Anthozoa & $\begin{array}{l}\text { Myriopathes } \\
\text { myriophylla }\end{array}$ & 212 & 50.5 & 227 & 58.1 & AM404328 \\
\hline class Hydrozoa & Craspedacusta sinensis & 251 & 48.2 & 291 & 54.3 & AY730675 \\
\hline class Scyphozoa & Manania uchidai & 245 & 48.6 & 234 & 49.1 & KU308635 \\
\hline \multicolumn{7}{|c|}{ phylum CTENOPHORA } \\
\hline \multirow[t]{2}{*}{ class Sagittoidea } & $\begin{array}{l}\text { Caecosagitta } \\
\text { macrocephala }\end{array}$ & 360 & 62.2 & & & AB505690 \\
\hline & Sagitta elegans & & & 258 & 65.1 & AF342799 \\
\hline \multicolumn{7}{|c|}{ phylum ECHINODERMATA } \\
\hline class Holothurioidea & Apostichopus japonicus & 518 & 64.5 & 434 & 67.5 & AB595141 \\
\hline \multirow[t]{2}{*}{ class Echinoidea } & Paracentrotus lividus & 429 & 58.8 & 360 & 61.7 & AJ457832 \\
\hline & $\begin{array}{l}\text { Strongylocentrotus } \\
\text { purpuratus }\end{array}$ & 430 & 60.5 & 387 & 60.5 & NW_011993745* \\
\hline \multicolumn{7}{|c|}{ phylum CTENOPHORA } \\
\hline \multirow[t]{3}{*}{ class Enteropneusta } & $\begin{array}{l}\text { Saccoglossus } \\
\text { kowalevskii }\end{array}$ & 444 & 58.6 & 450 & 62.2 & ACQM00000000* \\
\hline & Ptychodera flava & 361 & 68.4 & 242 & 74.8 & LC014161 \\
\hline & $\begin{array}{l}\text { Balanoglossus } \\
\text { carnosus }\end{array}$ & 335 & 68.4 & 286 & 73.1 & LC012597 \\
\hline \multicolumn{7}{|c|}{ phylum CHORDATA } \\
\hline \multicolumn{7}{|c|}{ subphylum Cephalochordata } \\
\hline class Leptocardii & Branchiostoma floridae & 903 & 64.9 & 364 & 69.2 & ABEP00000000* \\
\hline
\end{tabular}


bioRxiv preprint doi: https://doi.org/10.1101/112797; this version posted March 1, 2017. The copyright holder for this preprint (which was not certified by peer review) is the author/funder, who has granted bioRxiv a license to display the preprint in perpetuity. It is made available under aCC-BY-NC-ND 4.0 International license.

\begin{tabular}{|c|c|c|c|c|c|c|}
\hline \multirow[t]{2}{*}{ Taxonomic group } & \multirow[t]{2}{*}{ Species } & \multicolumn{2}{|c|}{ ITS1 } & \multicolumn{2}{|c|}{ ITS2 } & \multirow{2}{*}{$\begin{array}{c}\text { Source } \\
\text { (*unannotated sequences) }\end{array}$} \\
\hline & & $\mathrm{L}$ & GC\% & $\mathrm{L}$ & GC\% & \\
\hline \multicolumn{7}{|c|}{ subphylum Tunicata } \\
\hline \multirow[t]{2}{*}{ class Ascidiacea } & Ciona savignyi & 224 & 62.5 & 313 & 68.7 & ААСТ00000000* \\
\hline & Herdmania momus & 286 & 64.3 & 276 & 69.9 & X53538 \\
\hline class Appendicularia & Oikopleura dioica & 295 & 44.1 & 209 & 46.4 & CABV01004439* \\
\hline \multicolumn{7}{|c|}{ subphylum Vertebrata } \\
\hline class Cyclostomata & Petromyzon marinus & 307 & 66.8 & 313 & 67.1 & $\begin{array}{c}\text { AEFG00000000* } \\
\text { AF061798 } \\
\end{array}$ \\
\hline \multicolumn{7}{|c|}{ class Chondrichthyes } \\
\hline \multirow[t]{2}{*}{ subclass Holocephali } & Callorhinchus milii & 730 & 72.9 & 429 & 77.7 & AAVX00000000* \\
\hline & Hydrolagus colliei & & & 429 & 70.2 & AF061799 \\
\hline \multirow{2}{*}{$\begin{array}{l}\text { subclass } \\
\text { Elasmobranchii }\end{array}$} & Lamna ditropis & 1566 & 65.1 & & & AB375551 \\
\hline & $\begin{array}{l}\text { Rhizoprionodon } \\
\text { porosus }\end{array}$ & & & 1362 & 61.1 & JN008720 \\
\hline \multicolumn{7}{|c|}{ class Actinopterygii } \\
\hline \multirow[t]{5}{*}{ subclass Neopterygii } & Cyprinus carpio & 368 & 66.0 & 381 & 78.0 & AF133089 \\
\hline & Clarias camerunensis & 521 & 68.5 & 423 & 71.9 & AJ876402 \\
\hline & Heteropneustes fossilis & 409 & 64.8 & 431 & 68.6 & AJ876377 \\
\hline & $\begin{array}{l}\text { Aphanotorulus } \\
\text { ammophilus }\end{array}$ & 410 & 71.7 & 361 & 70.6 & AJ412872 \\
\hline & Auxis rochei & 602 & 71.4 & 398 & 72.1 & AB193743 \\
\hline \multicolumn{7}{|c|}{ class Sarcopterygii } \\
\hline subclass Actinistia & Latimeria chalumnae & 807 & 77.1 & 348 & 79.9 & BAHO00000000* \\
\hline \multicolumn{7}{|c|}{ superclass Tetrapoda } \\
\hline \multicolumn{7}{|c|}{ class Amphibia } \\
\hline \multirow{2}{*}{$\begin{array}{l}\text { subclass } \\
\text { Lissamphibia }\end{array}$} & Rana nigromaculata & 506 & 78.1 & 343 & 82.2 & AB099628 \\
\hline & Xenopus tropicalis & 499 & 75.6 & 337 & 78.9 & AAMC00000000* \\
\hline \multicolumn{7}{|c|}{ clade Sauropsida } \\
\hline \multicolumn{7}{|c|}{ class Reptilia } \\
\hline \multirow[t]{5}{*}{ order Squamata } & Anolis humilis & 1029 & 75.2 & & & KJ523027 \\
\hline & Ctenosaura bakeri & & & 439 & 80.9 & EU407546 \\
\hline & Crotalus mitchellii & 1526 & 79.0 & 630 & 81.0 & JPMF00000000* \\
\hline & Ophiophagus haah & 1599 & 78.4 & 645 & 83.1 & AZIM00000000* \\
\hline & $\begin{array}{l}\text { Protobothrops } \\
\text { mucrosquamatus }\end{array}$ & 1568 & 78.1 & 621 & 81.0 & BCNE02005998* \\
\hline \multirow[t]{2}{*}{ order Testudines } & Geochelone nigra & 2007 & 53.9 & & & AY101758 \\
\hline & Chrysemys picta & 1413 & 72.4 & 928 & 73.9 & AHGY00000000* \\
\hline \multirow[t]{2}{*}{ order Crocodilia } & Crocodylus siamensis & 1561 & 61.9 & 830 & 65.3 & EU727190 \\
\hline & $\begin{array}{l}\text { Alligator } \\
\text { mississippiensis }\end{array}$ & 1690 & 65.5 & 850 & 67.3 & AKHW00000000* \\
\hline \multicolumn{7}{|c|}{ class Aves } \\
\hline $\begin{array}{l}\text { order } \\
\text { Apterygiformes }\end{array}$ & Apteryx australis & 3144 & 81.0 & 1257 & 81.8 & $\begin{array}{c}\text { ERX487302* ERX487299* } \\
\text { ERX484520* } \\
\text { NW_013995077* } \\
\text { NW_013988608* }\end{array}$ \\
\hline order Gallifirmes & Gallus gallus & 2530 & 82.2 & 733 & 82.1 & KT445934 \\
\hline & Coturnix coturnix & 2176 & 78.1 & 666 & 79.0 & DRX001709* \\
\hline order Columbiformes & Columba livia & 3003 & 80.2 & 649 & 80.6 & SRX1034682* \\
\hline $\begin{array}{l}\text { order } \\
\text { Charadriiformes }\end{array}$ & Calidris pugnax & 2551 & 83.0 & 643 & 79.3 & ERX1097215* \\
\hline $\begin{array}{l}\text { order } \\
\text { Accipitriformes }\end{array}$ & Aquila chrysaetos & 2765 & 81.3 & 716 & 80.2 & SRX710379* \\
\hline order Psittaciformes & Ara macao & 2004 & 80.6 & & & AOUJ00000000* \\
\hline & $\begin{array}{l}\text { Melopsittacus } \\
\text { undulates }\end{array}$ & & & 593 & 78.6 & AGAI00000000* \\
\hline
\end{tabular}


bioRxiv preprint doi: https://doi.org/10.1101/112797; this version posted March 1, 2017. The copyright holder for this preprint (which was not certified by peer review) is the author/funder, who has granted bioRxiv a license to display the preprint in perpetuity. It is made available under aCC-BY-NC-ND 4.0 International license.

\begin{tabular}{|c|c|c|c|c|c|c|}
\hline \multirow{2}{*}{ Taxonomic group } & \multirow{2}{*}{ Species } & \multicolumn{2}{|c|}{ ITS1 } & \multicolumn{2}{|c|}{ ITS2 } & \multirow{2}{*}{$\begin{array}{c}\text { Source } \\
(* \text { unannotated sequences) }\end{array}$} \\
\hline & & $\mathrm{L}$ & GC\% & $\mathrm{L}$ & GC\% & \\
\hline \multirow[t]{6}{*}{ order Passeriformes } & Geospiza fortis & 2955 & 81.4 & 876 & 66.4 & SRX728502* SRX728501* \\
\hline & & & & & & SRX728503* \\
\hline & Zonotrichia albicollis & & & 901 & 61.5 & SRX871640 \\
\hline & Taeniopygia guttata & 2767 & 81.9 & 874 & 76.7 & SRX1205094* \\
\hline & & & & & & SRX1205425* \\
\hline & Sturnus vulgaris & 3075 & 78.9 & 822 & 64.4 & SRX1182705* \\
\hline \multicolumn{7}{|c|}{ clade Synapsida } \\
\hline \multicolumn{7}{|c|}{ class Mammalia } \\
\hline $\begin{array}{l}\text { order } \\
\text { Didelphimorphia }\end{array}$ & Monodelphis domestica & 3080 & 74.1 & 740 & 73.2 & Coleman, 2013 \\
\hline order Afrosoricida & Echinops telfairi & 1786 & 75.5 & 1405 & 76.5 & Coleman, 2013 \\
\hline order Proboscidea & Loxodonta africana & 1660 & 81.0 & 1350 & 84.1 & Coleman, 2013 \\
\hline order Cingulata & Dasypus novemcinctus & 1111 & 78.8 & 1089 & 84.5 & Coleman, 2013 \\
\hline order Pilosa & Choloepus hoffmanni & 1343 & 76.8 & 1148 & 79.5 & Coleman, 2013 \\
\hline order Chiroptera & Myotis lucifugus & 1242 & 76.2 & 789 & 75.5 & Coleman, 2013 \\
\hline order Carnivora & Canis lupus & 1865 & 80.5 & 1116 & 73.8 & Coleman, 2013 \\
\hline order Perissodactyla & Equus caballus & 1430 & 81.0 & 1149 & 85.4 & Coleman, 2013 \\
\hline order Artiodactyla & Bubalus bubalis & 1465 & 74.7 & 966 & 67.8 & JN412502 \\
\hline order Cetacea & Tursiops truncatus & 1823 & 78.9 & 1327 & 80.5 & Coleman, 2013 \\
\hline order Soricomorpha & Sorex araneus & 1302 & 77.7 & 924 & 79.8 & Coleman, 2013 \\
\hline $\begin{array}{l}\text { order } \\
\text { Erinaceomorpha }\end{array}$ & Erinaceus europaeus & 1526 & 74.2 & 953 & 77.2 & Coleman, 2013 \\
\hline order Primates & Homo sapiens & 1095 & 79.6 & 1155 & 83.1 & U13369 \\
\hline order Scandentia & Tupaia belangeri & 1430 & 76.2 & 1567 & 78.9 & Coleman, 2013 \\
\hline order Rodentia & Rattus norvegicus & 1066 & 74.6 & 764 & 79.8 & NR_046239 \\
\hline order Lagomorpha & Oryctolagus cuniculus & 1595 & 73.8 & 1113 & 76.9 & Coleman, 2013 \\
\hline
\end{tabular}

\subsection{ITSs structural trends in Deuterostomia evolution}

We have analyzed Deuterostomia ITSs structural changes in two evolutionary vectors: from Chaetognatha to Reptilia-Aves (Sauropsida), and from Chaetognatha to Mammalia (Sinapsida). For simplification both these vectors are represented in separate charts designated as Sauropsida line and Synapsida line respectively. In both charts taxa layout is based on their evolutionary proximity. However, closely located taxa are not necessarily ancestors to or descendants of each other.

\subsubsection{ITS1 and ITS2 sequence length change}

ITSs length change in Sauropsida and Synapsida lines is shown in Figures 2 and 3 respectively. By ITSs length change nature both lines clearly fall into two parts. Within the left part (Chaetognatha - Amphibia) the average lengths of both ITSs are 1.5 times as much as ITS lengths in the outgroup: ITS1 - 419 bp, ITS2 - 364 bp vs 230 bp and 254 bp in Ctenophora and Cnidaria respectively (Fig. 4). Generally no clear relation between spacer length change and evolutionary development of animal structure can be identified here. The only exception are ITS lengths in the analyzed Elasmobranchii (ITS1 in Lamna ditropis - 1566 bp; ITS2 in Rhizoprionodon porosus - 1362 bp), which considerably exceed the average ITSs lengths within 
this group. In terms of ITS1 length also stand out lancelet (Branchiostoma floridae) and coelacanth (Latimeria chalumnae) (Fig. 2 and 3). The above exceptions are in line with high variability of ITS1 (Fig. 4). Yet, generally ITS1 and ITS2 average lengths in the first chart part are approximately equal, ITS1 being only slightly longer than ITS2 (Fig. 5).

The right sections of charts 2 and 3 consist of ITS1 and ITS2 sequences of Sauropsida (Reptilia, Aves) and Sinapsida (Mammalia) respectively. Both in Sauropsida and Sinapsida both spacers are considerably longer than those of Chaetognata-Amphibia and outgroup. In Sauropsida line ITS2 length increases smoothly with transition from anamniotes to amniotes (Fig. 2); towards Aves the disproportion in ITS1 and ITS2 length increases (Fig. 6). ITS1 sequence in kiwi (Apteryx australis) of 3144 bp is the longest among the analyzed animal species. Taking into account the data reported by Coleman (2013), this value is the ceiling in Deuterostomia. Among Sauropsida, kiwi also features the longest ITS2 of 1257 bp. ITS2 length in kiwi, a member of Paleognathae, considerably differs from ITS2 of the analyzed avian species, sub-class Neognathae, and reptiles whose ITS2 is 1.5-2 times shorter.

In Sinapsida evolutionary line the length of both spacers sharply increases in mammals (Fig. 3). In most of the analyzed species ITS1 is slightly longer than ITS2 (Fig. 7). In placental mammals, ITS1 to ITS2 length ratio is similar to most amniotes, the average being around 1.32. Contrarily to birds and reptiles, in mammals ITS1 and ITS2 lengths vary widely even among close orders (Fig. 3, 7).

Marsupial Monodelphis domestica constitutes a noteworthy exception. The extraordinarily long ITS1 (3080 bp) in this species combines with a short ITS2 of 740 bp. This situation is common to birds and some reptiles, yet not to mammals. 
bioRxiv preprint doi: https://doi.org/10.1101/112797; this version posted March 1, 2017. The copyright holder for this preprint (which was

not certified by peer review) is the author/funder, who has granted bioRxiv a license to display the preprint in perpetuity. It is made available under aCC-BY-NC-ND 4.0 International license.

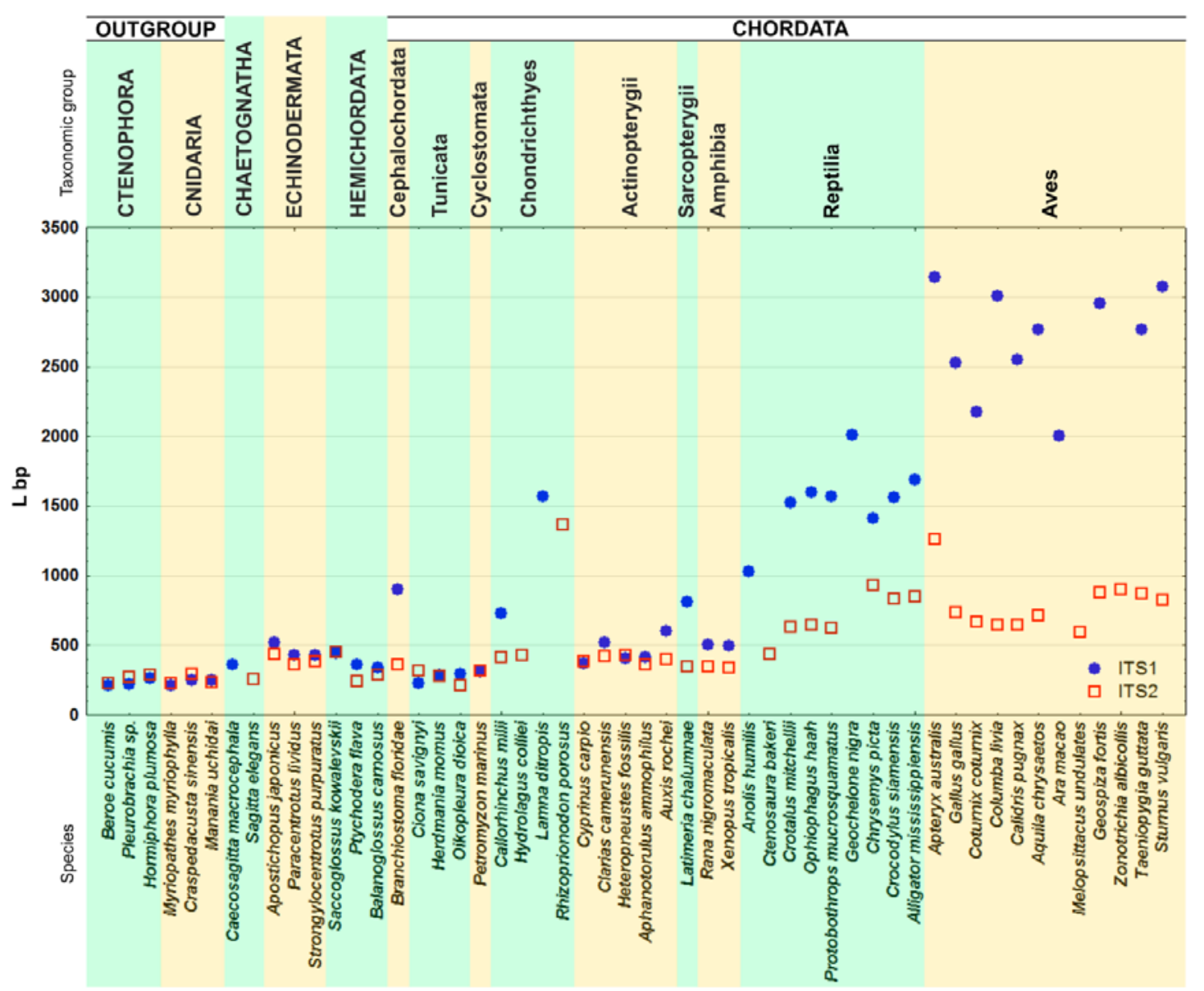

Fig. 2. ITS1 and ITS2 lengths in Deuterostomia taxa. Sauropsida evolutionary line

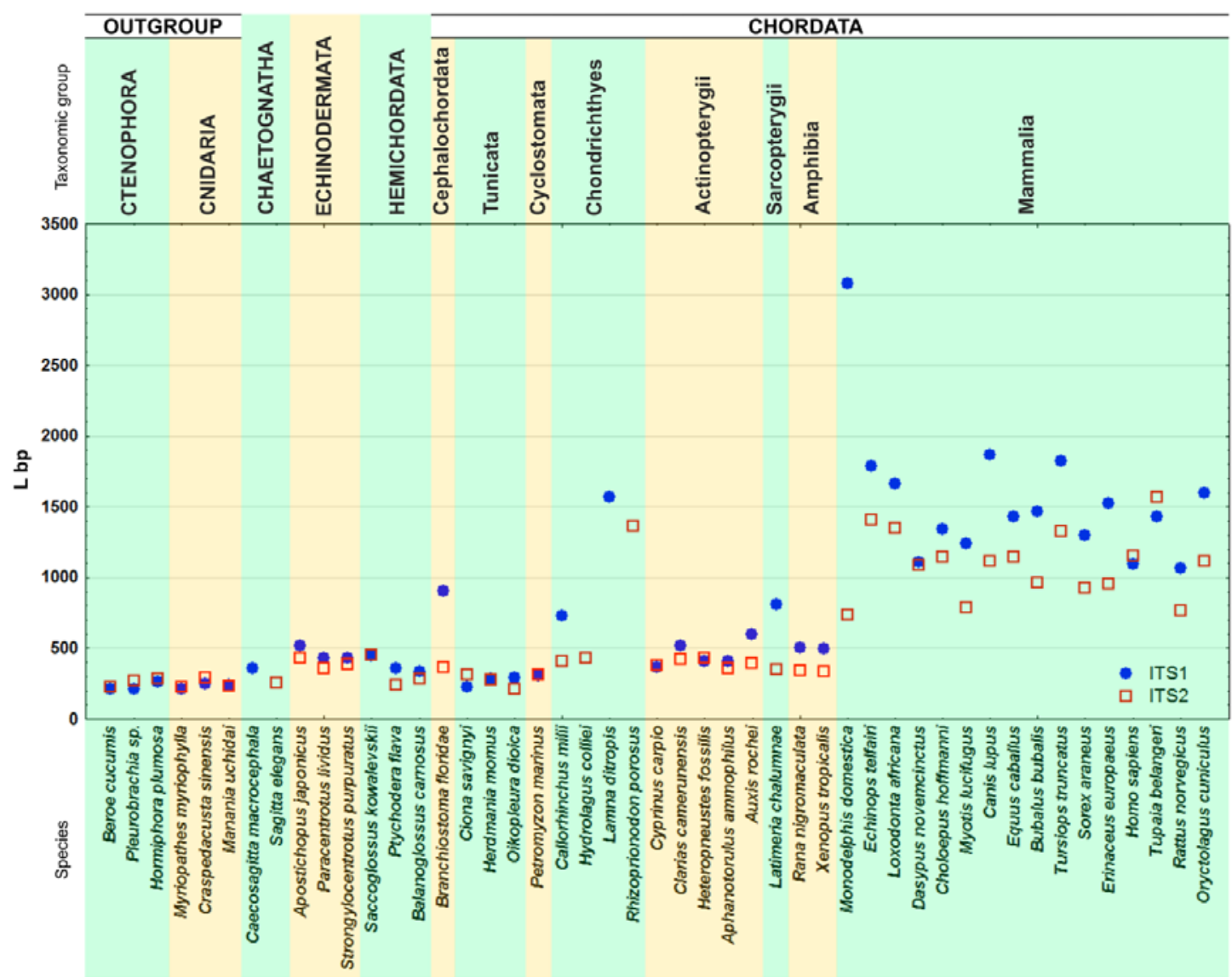

Fig. 3. ITS1 and ITS2 lengths in Deuterostomia taxa. Synapsida evolutionary line 


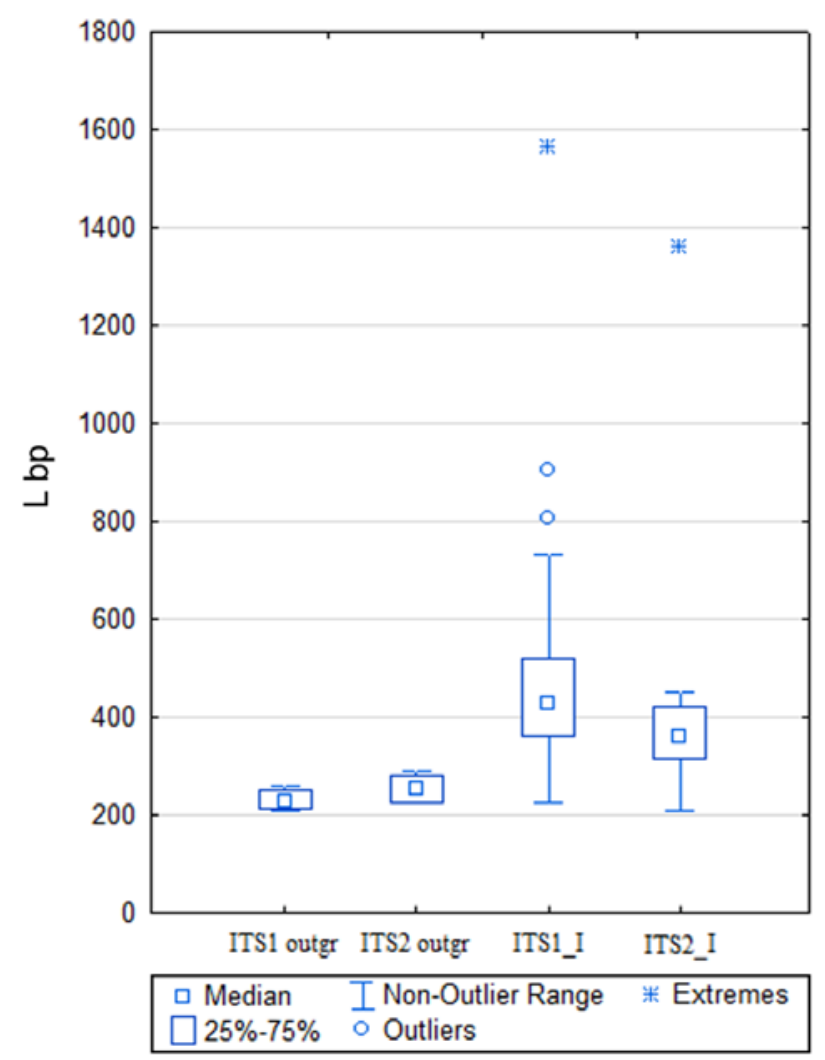

Fig. 4. Box plot of ITS1 and ITS2 lengths in Chaetognatha-Amphibia.

ITS1_I and ITS2_I - ITS1 and ITS2 sequence lengths in Chaetognatha-Amphibia species. ITS1_outgr and ITS2_outgr - ITS1 and ITS2 sequence lengths in Chaetognatha-Amphibia species.

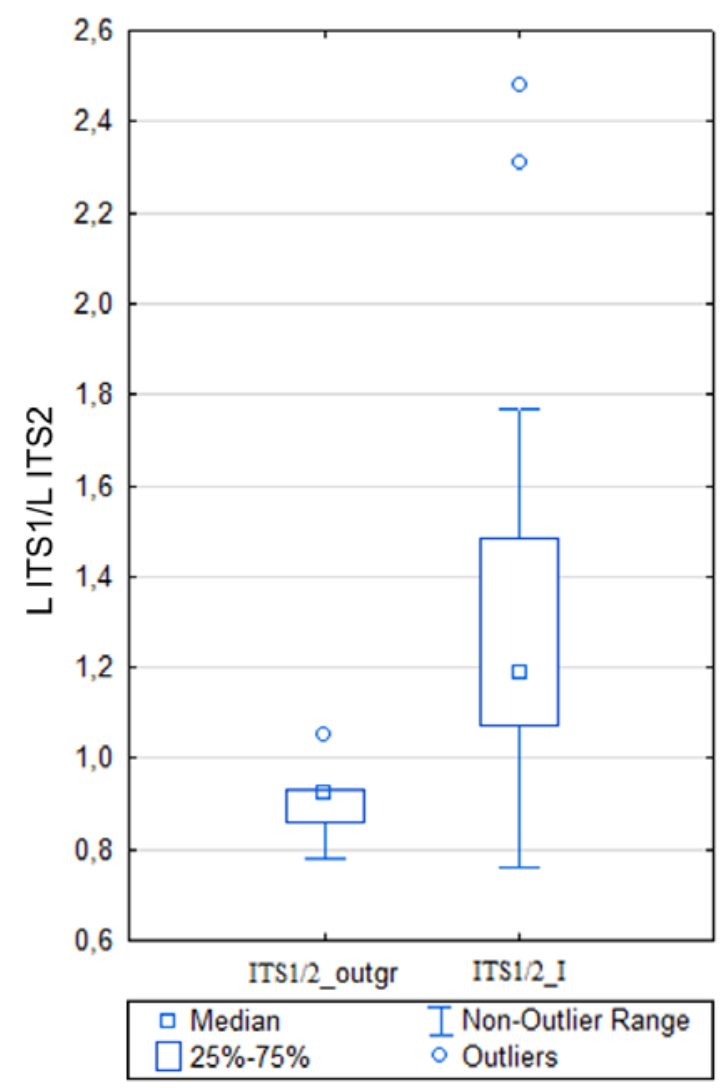

Fig. 5. ITS1 to ITS2 length ratio in Chaetognatha-Amphibia.

ITS1/2_outgr - ITS1 to ITS2 length ratio in Ctenophora и Cnidaria species; ITS1/2_I - ITS1 to ITS2 length ratio in Chaetognatha-Amphibia species. 


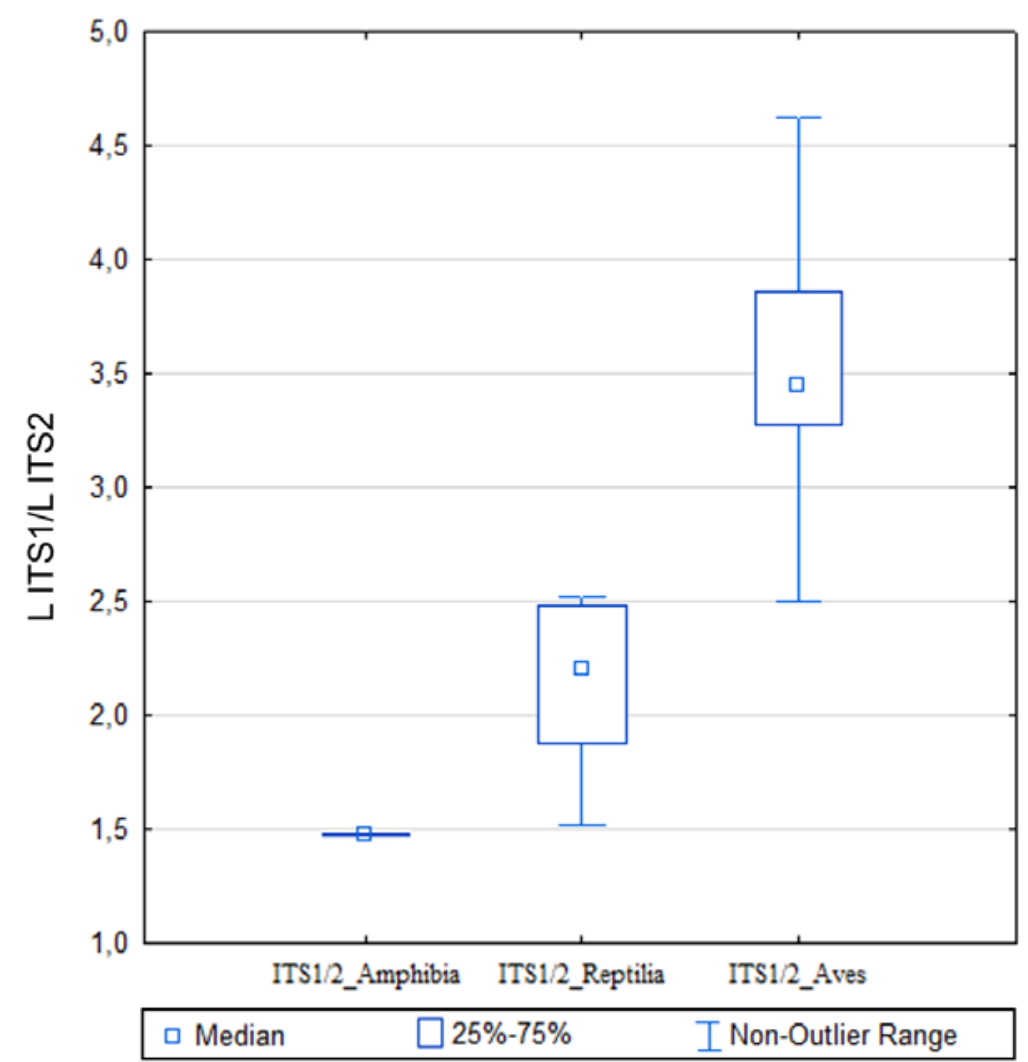

Fig. 6. ITS1 to ITS2 length ratio in Amphibia (ITS1/2_Amphibia), Reptilia (ITS1/2_Reptilia) and Aves (ITS1/2_Aves).

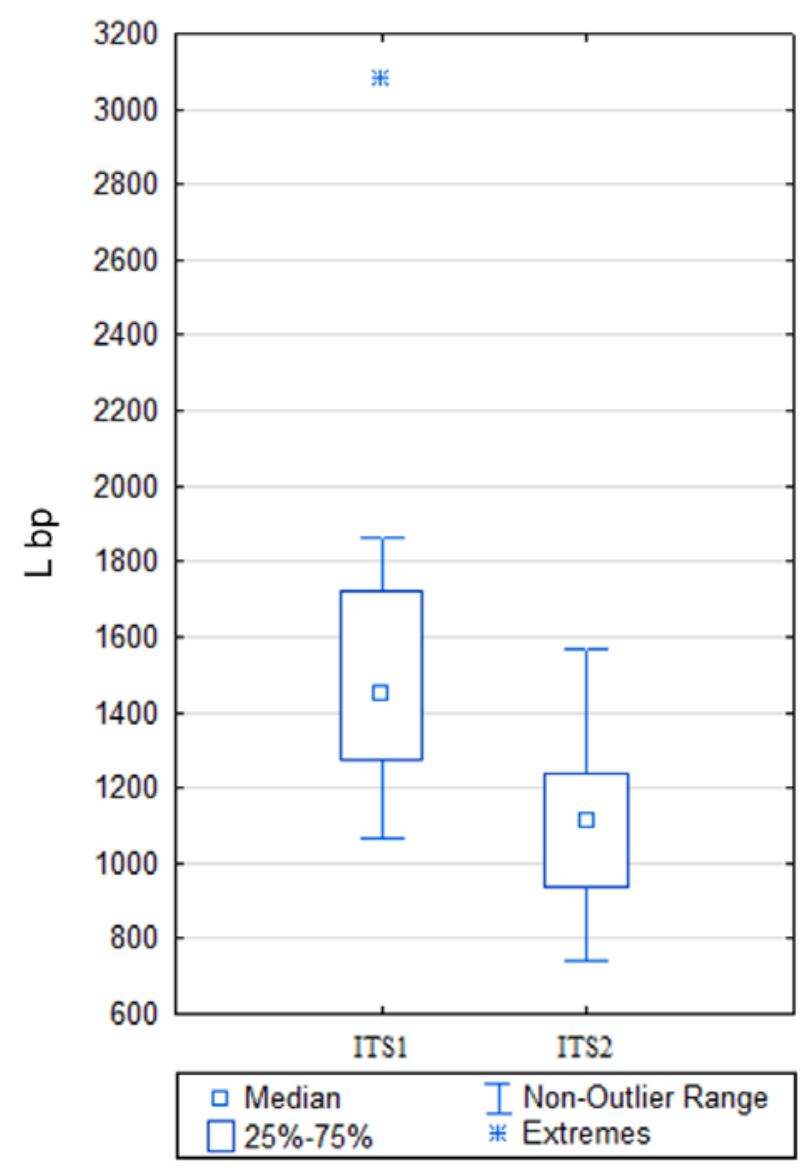

Fig. 7. ITS1 and ITS2 length range in Mammals. 


\subsubsection{GC pair content variation}

GC pair content variation in Sauropsida and Sinapsida evolutionary lines is shown in Figures 8 and 9 respectively. In both charts a smooth GC-content increase can be seen in both ITS1 and ITS2 from Ctenophora, Cnidaria, and primitive Deuterostomia to terrestrial vertebrates. In Chaetognatha and Echinodermata, GC pair content is about 61\% in ITS1 and 63\% in ITS2. In coelacanth (Sarcopterigii), GC pair content in ITSs achieves as much as $75-80 \%$ and increases further to $82-85 \%$ in birds and mammals.

Most taxa, with the exception of Aves, feature a higher GC-content in ITS2 compared to ITS1 (Fig. 10A). Concurrently, in most taxa GC-content in ITS1 and ITS2 is virtually the same within the same species: the difference generally does not exceed $8 \%$, the average being 3.3\% and close to 0\% in some species (Fig. 10B). Torres et al. (1990) obtained similar results from spacer analysis of some evolutionarily remote eukaryotes. This phenomenon prompts the existence of some concerted evolution patterns stabilizing ITS1 and ITS2 nucleotide content in Deuterostomia.

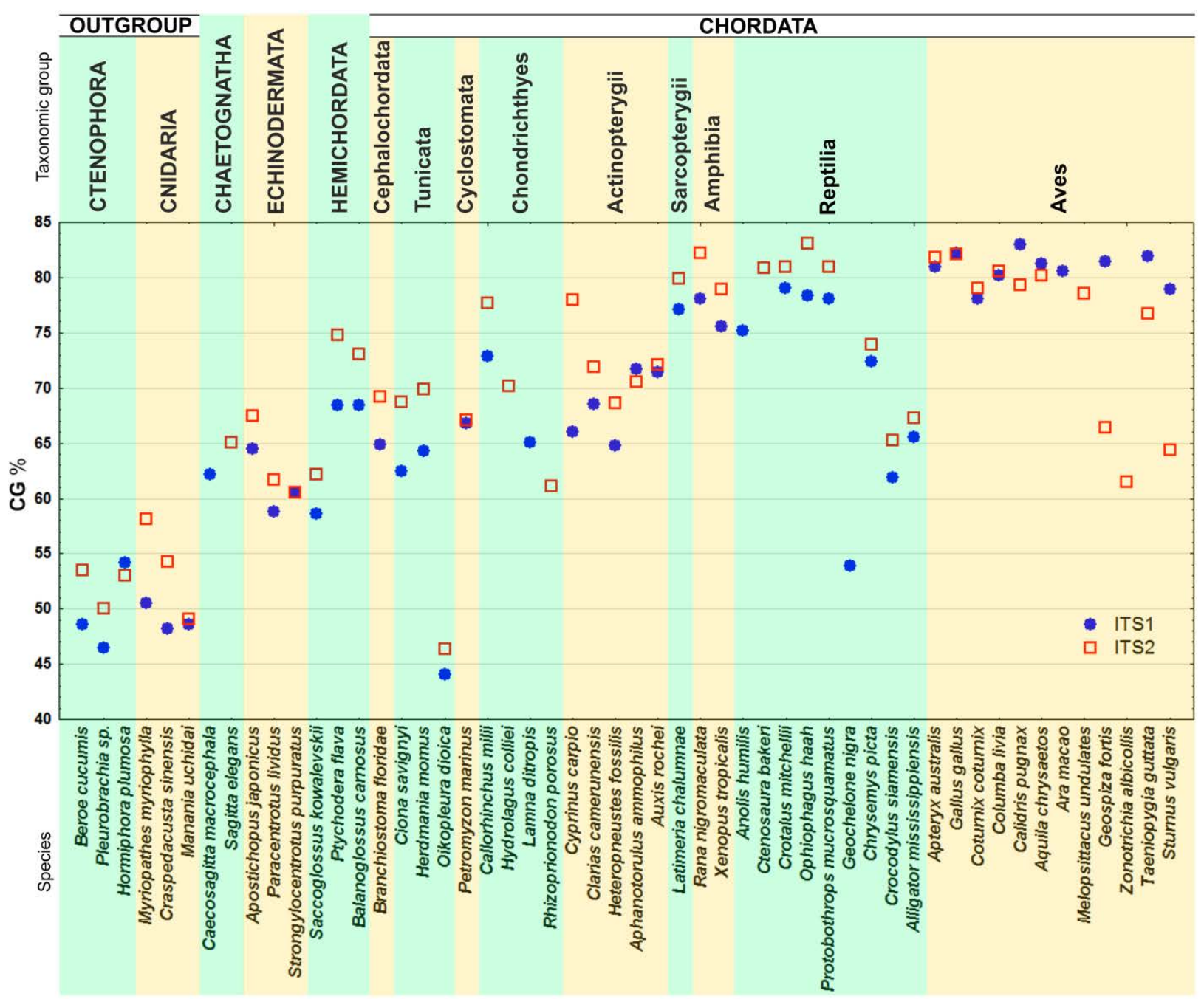

Fig. 8. GC-content in ITS1 and ITS2 sequences in Sauropsida evolutionary line 


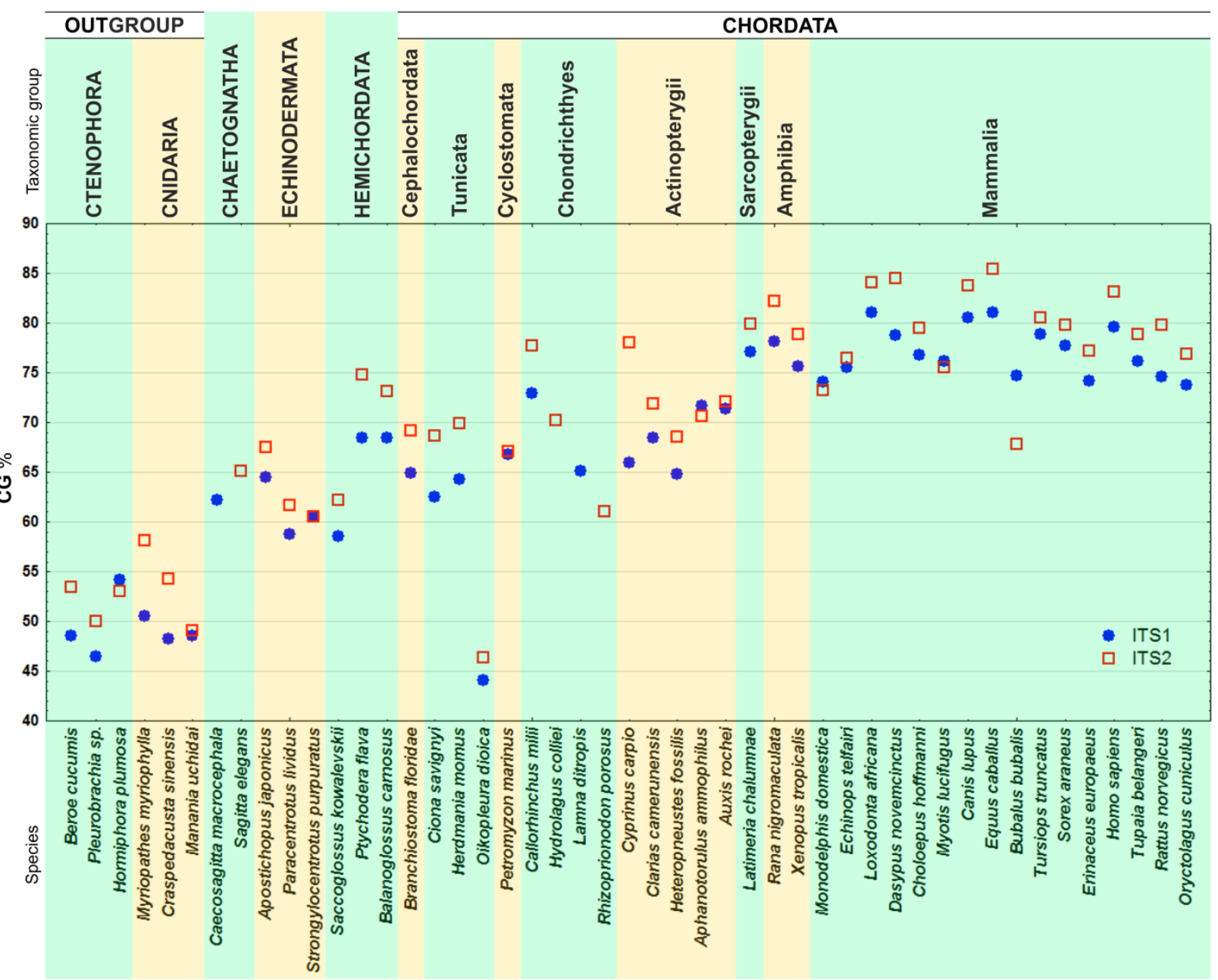

Fig. 9. GC-content in ITS1 and ITS2 sequences in Synapsida evolutionary line
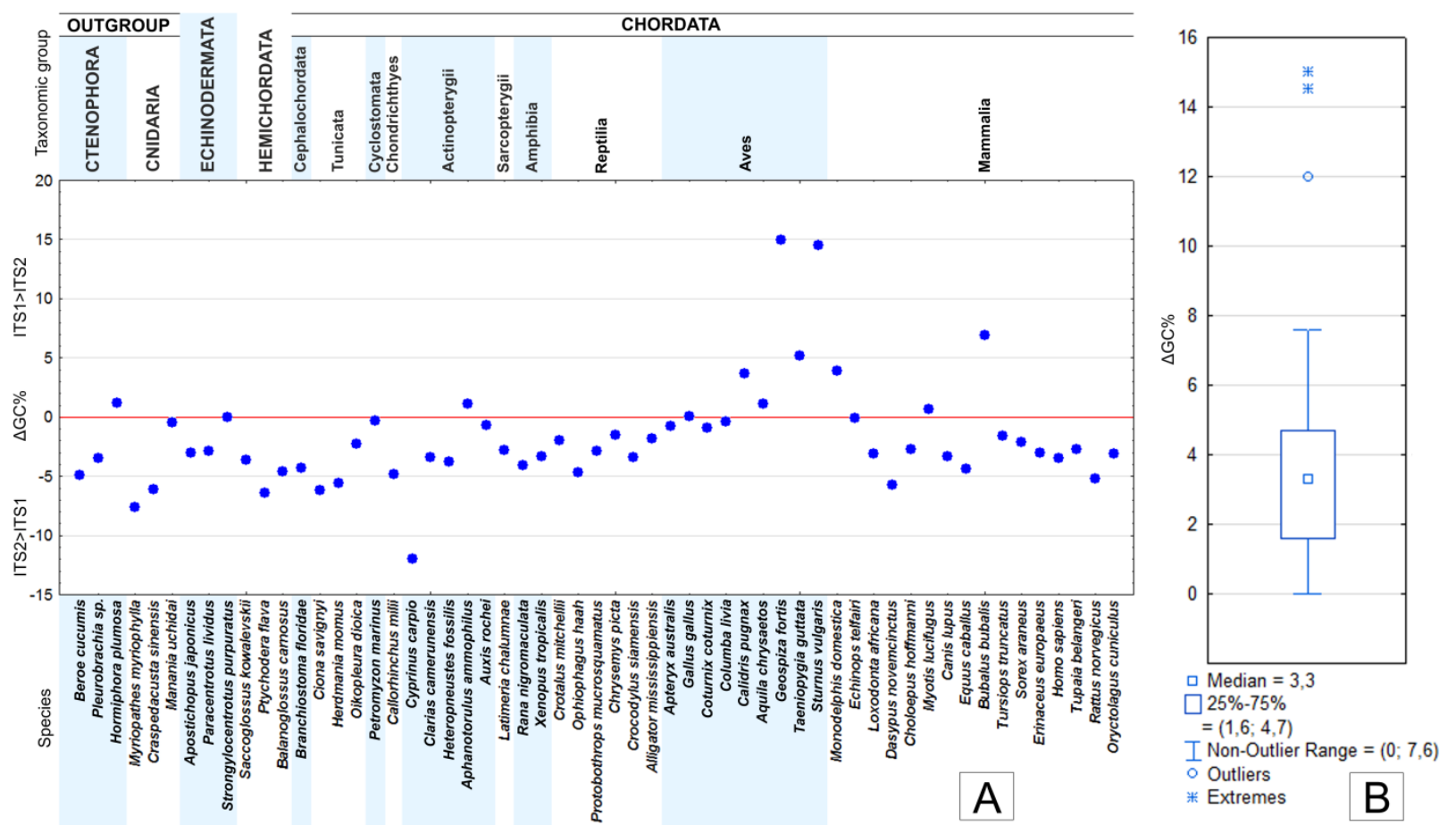

Fig. 10. A. GC-content variation in ITS1 and ITS2 in the analyzed Deuterostomia species. B. Box plot of $\triangle \mathrm{GC} \%$ in ITS1 and ITS2 in the analyzed Deuterostomia species 


\subsubsection{Nucleotide compositional shift in the sense DNA sequences of ITS1 and ITS2 in}

\section{Deuterostomia}

The charts in Figures 11 and 12 show nucleotide compositional shift in ITS sense of Deuterostomia DNA sequences. The situation observed is generally common to both spacers. Their adenine content is higher than thymine content in the majority of the analyzed species. This feature can already be detected in Ctenophora and Cnidaria members. In Siamese crocodile (Crocodylus siamensis) the ITS1 nucleotide balance shifts towards a higher adenine content. A considerable shift has been recorded only in mammals. In ITS2 adenine content increase starts with lamprey ( $P$. marinus) and is well-marked in most vertebrates. Guanine and cytosine content in ITS sense DNA sequences varies insignificantly and virtually stabilizes in painted turtle (Chrysemys picta). Therefore, the observed thymine content decrease in ITS sense DNA chains correlates to GC-content in double strength DNA of these sequences.

Earlier methyl-cytosine deamination in CpG dinucleotides was shown to be involved in plant ITS1 and ITS2 alteration towards AT-content increase (Torres et al., 1990). The GCcontent increase in Deuterotomia described by these authors is likely to be related to the effect of other mechanisms.

\subsection{Peculiarities of GC-content in Sauropsida ITS1 and ITS2}

The reported common patterns of GC-content variation in Deuterostomia ITS1 and ITS2 include a number of exceptions requiring special focus.

In the segment of the chart (Fig. 8) showing GC-content in Sauropsida ITSs, we can clearly see a region of GC-content collapse in turtles and crocodiles. GC-content in both ITSs is by $20-25 \%$ lower in crocodiles (C. siamensis and Alligator mississippiensis) and $10-15 \%$ in turtles (C. picta) compared to the rest of Sauropsida. This phenomenon stands out of the general GC increase trend in ITSs associated with Deuterostomia evolution. We assume that this phenomenon could be related to expansion of AT-enriched mobile genetic elements (MGC) in spacer sequence. Thus, in Galapagos tortoise (Geochelone nigra) ITS1 featuring a length of 2007 bp and 54 GC-content (NCBI, Nucleotide: AY101758), we have found an AT-enriched fragment of 880 bp (Supplementary File 2). The similarity of this fragment to non-LTR retrotransposon CR1-4 CPB sequence achieves 93\%. NCBI database contains 15 complete ITS1 sequences of five Geochelone species (NCBI, Nucleotide: AY101749-AY101763) including AT-enriched fragments that are also homologous to CR1-4 CPB. The repetitiveness of such cases excludes the probability of an artifact. MGE presence in ITSs Deuterostomia sequences has not been reported earlier. MGE insertion is likely to be one of ITSs evolutionary patterns. MGE insertions have not been found in the ITSs of other analyzed Deuterostomia taxa. The homology of insertions and 
bioRxiv preprint doi: https://doi.org/10.1101/112797; this version posted March 1, 2017. The copyright holder for this preprint (which was

not certified by peer review) is the author/funder, who has granted bioRxiv a license to display the preprint in perpetuity. It is made available under aCC-BY-NC-ND 4.0 International license.

source MGE sequences could have been terminated due to the high evolutionary rate of rDNA spacers (Wang et al., 2015).

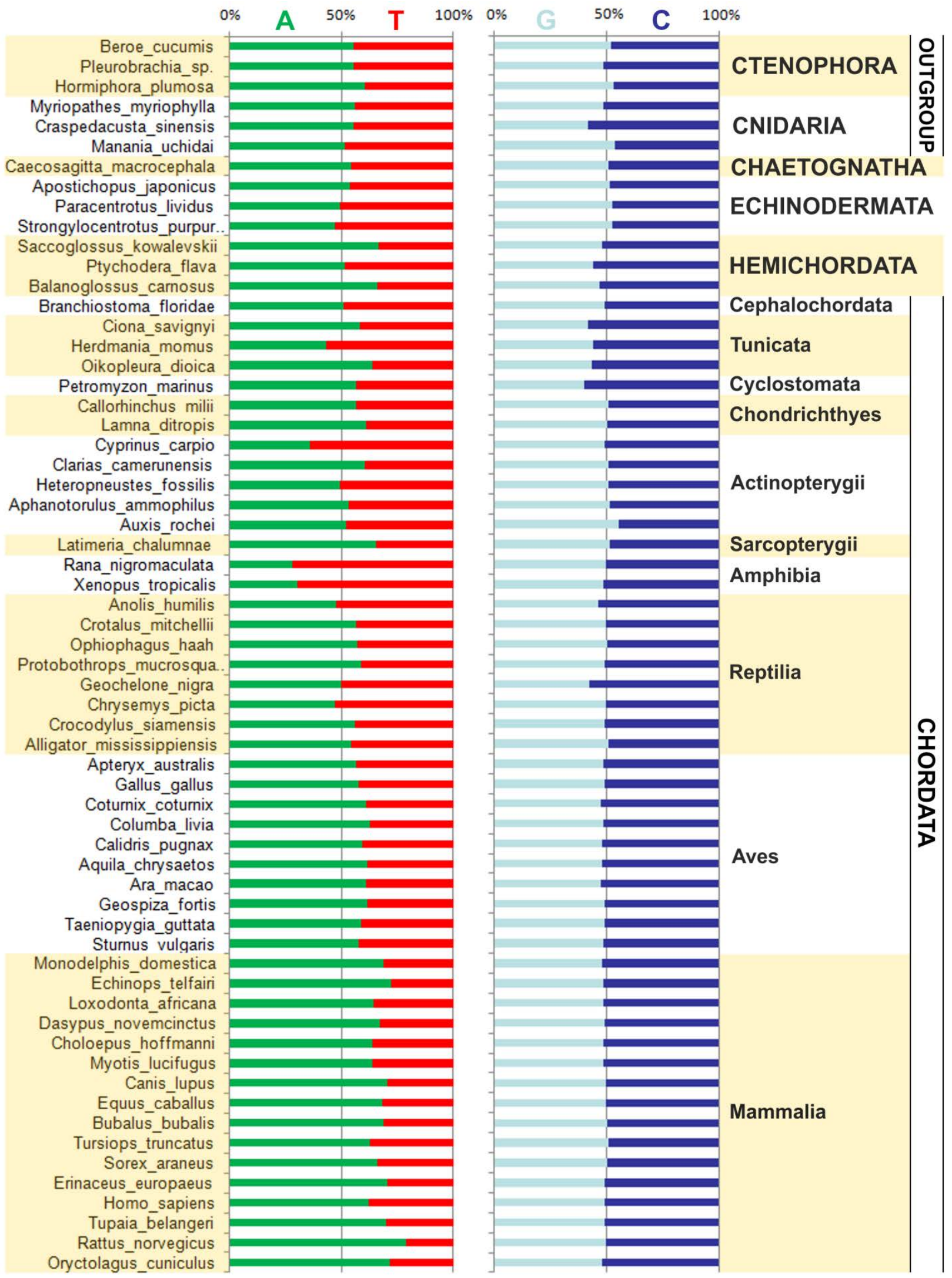

Fig. 11. Nucleotide composition shift in ITS1 sense DNA sequences 
bioRxiv preprint doi: https://doi.org/10.1101/112797; this version posted March 1, 2017. The copyright holder for this preprint (which was

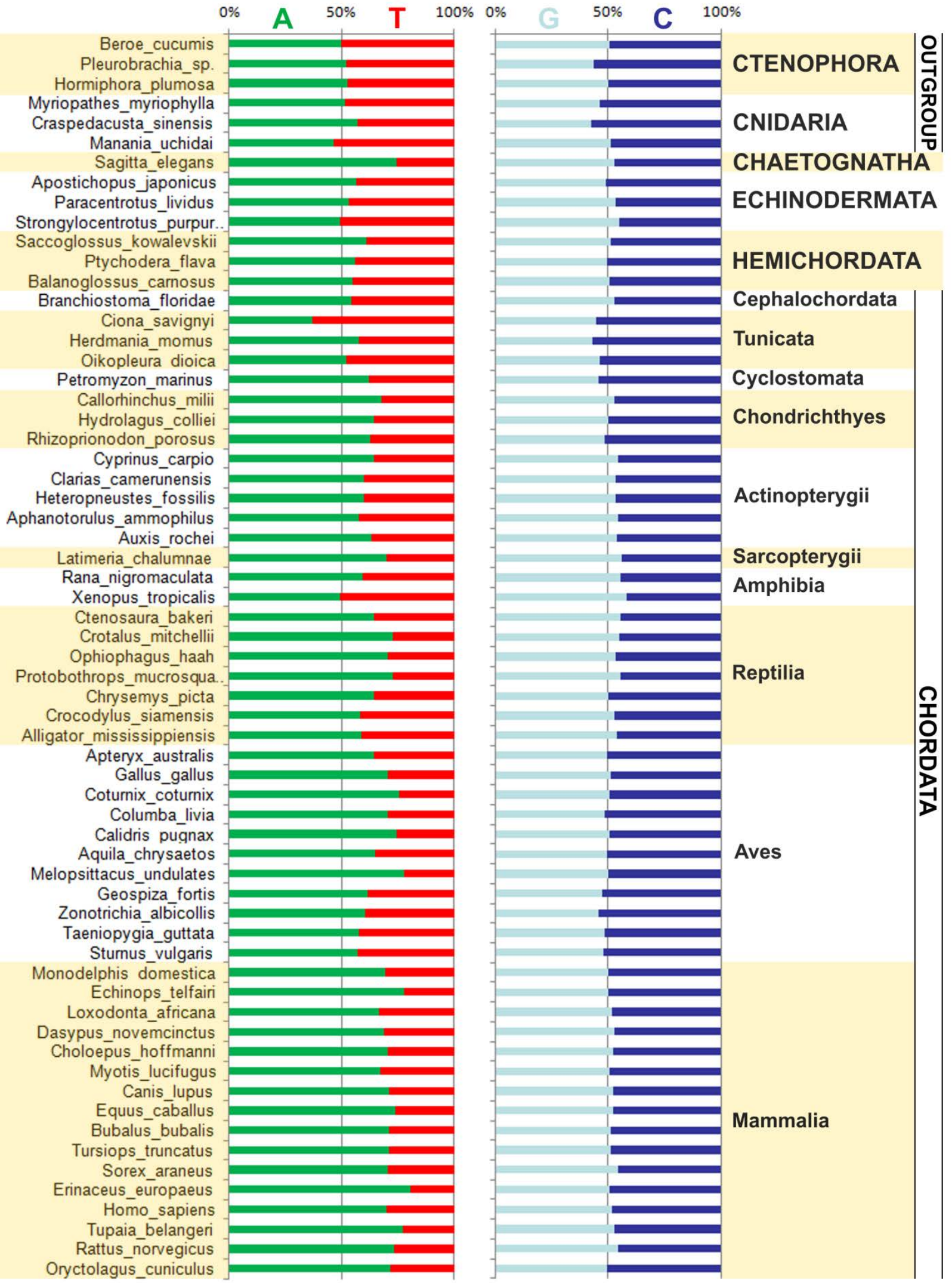

Fig. 12. Nucleotide composition shift in ITS2 sense DNA sequences 
In birds, from ruff (Calidris pugnax) and onwards, GC-content in ITS2 decreases compared to ITS1 (Fig. 7), which is uncommon to the great majority of the analyzed taxa. In Passeriformes, the most numerous Aves order, GC-content in ITS2 is 1.5 times lower than that of other orders. For example, GC-content in zonotrichia (Zonotrichia albicollis) ITS2 is 61,5\%, while in other orders its can achieve as much as 80\%. GC-content in ITS1 exceeds ITS2 by 15\% in medium ground finch (Geospiza fortis) (Fig. 9). ITS2 length in Passeriformes increases compared to the rest of the analyzed Aves, subclass Neognathae by at least 132 bp (Fig. 2). The insertions accounting for this increase are unique to Passeriformes and AT-enriched in 3 out of the 4 analyzed species. It is quite possible that MGE insertion could have caused variations in GC-content in Passeriformes ITS2 and in Galapagos tortoise.

\section{Discussion}

Our findings allow suggesting that internal transcribed spacer structural variation from inferior to superior taxa of Deuterostomia is associated with four key aspects: a) spacer length increase; b) GC-content increase in both ITSs; c) uniform GC-content in ITS1 and ITS2 within the same species; d) thymine content decrease in sense DNA sequences in both ITSs.

The most considerable ITSs extension has been identified in superior vertebrates and members of subclass Elasmobranchii (5-12 fold versus the members of the rest of the analyzed taxa). Superior vertebrates and Elasmobranchii are not sister taxa and have been evolving independently of each other. Convergent extension of ITSs of their members could be related to various selection factors. Both of these groups strongly differ ecologically and physiologically, so that physical environmental factors and the rate of metabolic processes appeared to have been of no key role in such changes.

ITSs length extension must have been related to the impact of focused selection, yet the true causes and patterns of this extension remain unclear. It would be feasible to analyze spacer length extension in the context of nucleotide composition shift. Spacer differences between close species of Deuterostomia are primarily defined by indels of several nucleotides or large fragments (of 20 or bp or longer). The possible role of MGE insertion in ITSs extension cannot be excluded either.

Contrarily to more primitive taxa of Deuterostomia, spacer extension within Amniota group evolved in two directions: in placental mammals both spacers generally extended commensurately, while in marsupials, reptiles and birds spacer length ratio shifted towards significant extension of ITS1 (2-3 fold). Probably, a similar disproportion could have been discovered in the common amniotic ancestor of Sauropsida and Sinapsida, which is specifically evidenced by the obviously disproportional spacer lengths of marsupial mammals. 
In the evolutionary line of Deuterostomia ITSs length extension is accompanied by ITSs nucleotide composition shift. Specifically, GC-content smoothly increases: the difference between primitive Deuterostomia (Chaetognatha and Echinodermata) and Tetrapoda and Sarcopterygii is about $15-20 \%$. Concurrently adenine content increases, while thymine content respectively decreases in ITS sense DNA sequences. The most likely pattern underlying this nucleotide composition shift could consist in GC-biased gene conversion (gBGC) leading to GCcontent increase for the account of gene conversion in the course of recombination and selective repair of the appearing non complementary TG pairs to CG (Fryxell and Zuckerkandl, 2000; Galtier et al., 2001; Duret and Galtier, 2009). gBGC phenomenon has been noted in a wide range of eukaryotes (Pessia et al., 2012), ectopic genetic conversion presumably being one of the core patterns of concerted evolution of rDNA repeat units (Naidoo et al., 2013). We could assume that the observed GC-content increase and thymine content decrease in Deuterostomia ITS with evolution is associated with the increasing gBGC capacity and/or impact of selection focused on GC pair binding in spacer sequences. The same processes could also account for sustaining GC/AT content similarity between internal transcribed spacers on intra-species basis.

ITSs length extension and the related GC-content increase lead to formation of infusible secondary structures containing multiple hairpins in pre-rRNA transcripts (Dyomin et al., 2016). The evolutionary effect of this spacer transformation remains unclear. Presumably, secondary structures are better recognized by pre-RNA splicing factors, which contributes to ribosome RNA formation. Furthermore, spliced pre-rRNA fragments enriched with G- and C-bases produced an enormous amount of double-stranded RNAs (dsRNA), whose further destiny is still unclear. Pre-rRNA synthesis rate has been reported to be consistently high in interphase nucleus and change considerably in the course of cell division (McStay and Grummt, 2008; Brown and Szyf, 2008). It is quite possible that in vertebrates, taking into account their advanced genetic chains, dsRNA forming from ITS transcripts could be one of the components of cell cycle genetic regulatory pattern.

\section{Acknowledgements}

The research has been financed by Saint-Petersburg State University (project number 1.50.1043.2014) and Russian Basic Research Foundation (project 15-04-05684). The work was performed on the base of «Chromas» resources centre of Saint-Petersburg State University Scientific Park. 


\section{Appendix A. Supplementary material}

Supplementary File 1

All ITS1 and ITS2 sequences used in this study

Supplementary File 2

Insertion of non-LTR retrotransposon CR1-4 CPB into Geochelone nigra ITS1 sequence

\section{References}

Bellemain, E., Carlsen, T., Brochmann, C., Coissac, E., Taberlet, P., Kauserud, H. 2010. ITS as an environmental DNA barcode for fungi: an in silico approach reveals potential PCR biases. BMC microbiology 10(1), 189.

Brown, S.E., Szyf, M. 2008. Dynamic epigenetic states of ribosomal RNA promoters during the cell cycle. Cell Cycle 7(3), 382-390.

Chen, S, Yao, H, Han, J, Liu, C, Song, J, Shi, L, Zhu, Y, Ma, X, Gao, T, Pang, X, Luo, K, Li, Y, Li, X, Jia, X, Lin, Y, Leon, C. 2010. Validation of the ITS2 region as a novel DNA barcode for identifying medicinal plant species. PloS one 5(1), e8613.

Coleman, A.W. (2007). Pan-eukaryote ITS2 homologies revealed by RNA secondary structure. Nucleic Acids Research 35(10), 3322-3329.

Coleman, A.W. 2013. Analysis of mammalian rDNA internal transcribed spacers. PloS one 8(11), e79122.

Cornman, R.S., Otto, C.R., Iwanowicz, D., Pettis, J.S. 2015. Taxonomic characterization of honey bee (Apis mellifera) pollen foraging based on non-overlapping paired-end sequencing of nuclear ribosomal loci. PloS one 10(12), e0145365.

Dunn, C.W, Hejnol, A., Matus, D.Q., Pang, K., Browne, W.E., Smith, S.A., Seaver, E., Rouse G.W., Obst, M., Edgecombe, G.D., Sørensen, M.V., Haddock, S.H., Schmidt-Rhaesa, A., Okusu, A., Kristensen, R.M., Wheeler, W.C., Martindale, M.Q., Giribet, G. 2008. Broad phylogenomic sampling improves resolution of the animal tree of life. Nature 452(7188), 745-749.

Duret, L., Galtier, N. 2009. Biased gene conversion and the evolution of mammalian genomic landscapes. Annual review of genomics and human genetics 10, 285-311.

Dyomin, A.G., Koshel, E.I., Kiselev, A.M., Saifitdinova, A.F., Galkina, S.A., Fukagawa, T., Kostareva, A.A., Gaginskaya, E.R. 2016. Chicken rRNA gene cluster structure. PloS one 11(6), e0157464.

Fryxell, K.J., Zuckerkandl, E. 2000. Cytosine deamination plays a primary role in the evolution of mammalian isochores. Molecular biology and evolution 17(9), 1371-1383. 
Galtier, N., Piganeau, G., Mouchiroud, D., Duret, L. 2001. GC-content evolution in mammalian genomes: the biased gene conversion hypothesis. Genetics 159(2), 907-911.

Hedges, S.B., Marin, J., Suleski, M., Paymer, M., Kumar, S. 2015. Tree of life reveals clock-like speciation and diversification. Molecular biology and evolution 32(4), 835-845.

http://www.geneious.com/

http://www.girinst.org/repbase/index.html

http://www.megasoftware.net/

http://www.ncbi.nlm.nih.gov/assembly/

http://www.ncbi.nlm.nih.gov/genome

http://www.ncbi.nlm.nih.gov/nuccore/

http://www.ncbi.nlm.nih.gov/sra/

http://www.ncbi.nlm.nih.gov/taxonomy/

http://www.statsoft.com/

https://blast.ncbi.nlm.nih.gov/Blast.cgi

Jarvis, E.D., Mirarab, S., Aberer, A.J., Li B., Houde, P., Li C., Ho S.Y., Faircloth, B.C., Nabholz, B., Howard, J.T., Suh A., Weber, C.C., da Fonseca, R.R., Alfaro-Núñez, A., Narula, N., Liu, L., Burt, D., Ellegren, H., Edwards, S.V., Stamatakis, A., Mindell, D.P., Cracraft, J., Braun, E.L., Warnow, T., Jun, W., Gilbert, M.T., Zhang, G. 2015. Phylogenomic analyses data of the avian phylogenomics project. GigaScience 4, 4.

Koepfli, K.P., Paten, B., O’Brien, S.J. 2015. The genome 10K project: a way forward. Annu. Rev. Anim. Biosci. 3(1), 57-111.

Kupriyanova, N., Shibalev, D., Voronov, A., Netchvolodov, K., Kurako, T., Ryskov, A. 2012. Vertebrate evolution reflected in the evolution of nuclear ribosomal internal transcribed spacer 2. Gene 508(1), 85-91.

McStay, B., Grummt, I. 2008. The epigenetics of rRNA genes: from molecular to chromosome biology. Annual review of cell and developmental biology 24, 131-157.

Naidoo, K., Steenkamp, E.T., Coetzee, M.P., Wingfield, M.J., Wingfield, B.D. 2013. Concerted evolution in the ribosomal RNA cistron. PLoS one 8(3), e59355.

Pessia, E., Popa, A., Mousset, S., Rezvoy, C., Duret, L., Marais, G.A. 2012. Evidence for widespread GC-biased gene conversion in eukaryotes. Genome Biology and Evolution 4(7), 787-794.

Singer M, Berg P. 1991. Genes and genomes, a changing perspective, University Science Books, Mill Valley.

Torres, R.A., Ganal, M., Hemleben, V. 1990. GC balance in the internal transcribed spacers ITS 1 and ITS 2 of nuclear ribosomal RNA genes. Journal of molecular evolution 30(2), 170-181. 
Wang, X.C., Liu, C., Huang, L., Bengtsson-Palme, J., Chen, H., Zhang, J.H., Cai D., Li, J.Q. 2015. ITS1: a DNA barcode better than ITS2 in eukaryotes? Molecular ecology resources 15(3), 573-586.

Yao, H., Song, J., Liu, C., Luo, K., Han, J., Li, Y., Pang, X., Xu, H., Zhu, Y., Xiao, P., Chen, S. 2010. Use of ITS2 region as the universal DNA barcode for plants and animals. PloS one 5(10), e13102.

Zagoskin, M.V., Lazareva, V.I., Grishanin, A.K., Mukha, D.V. 2014. Phylogenetic information content of Copepoda ribosomal DNA repeat units: ITS1 and ITS2 impact. BioMed research international 2014, 926342. 